\title{
2004年新潟県中越地震で被害を免れた RC 造校舎の 入力地震動と地震時応答に関する研究 \\ STUDY ON INPUT MOTION AND DYNAMIC RESPONSE FOR UNDAMAGED RC SCHOOL BUILDING DURING THE 2004 NIIGATA-KEN CHUETSU EARTHQUAKE
}

\author{
土方 勝一郎 ${ }^{* 1}$, 杉 山 達 也 ${ }^{* 2}$, 徳 光 亮 ${ }^{* 2}$ \\ 山添正稔*3, 古山田耕司*3, 岡 野 創*3, 宮本裕司*4 \\ Katsuichirou HIJIKATA, Tatsuya SUGIYAMA, Ryoichi TOKUMITSU, \\ Masatoshi YAMAZOE, Kohji KOYAMADA, Hajime OKANO and Yuji MIYAMOTO
}

\begin{abstract}
The goal of this study is to clarify dynamic responses of the Ojiya west high school that is near an observation site where severe ground motions were obtained during the 2004 Niigata-Chuetsu Earthquake. Firstly, field surveys of the superstructure and geological surveys were conducted. Next, simulation analyses were performed using the strong motions and the suppressible factors of structure damage were verified on the basis of the analyses results. Structural surveys clarified that both the superstructure and pile foundations of the school building had almost no damage by the earthquake. Geological surveys and site response analyses clarified that the surface clay layer strongly softened during the earthquake. Finally, simulation analyses by the 3-D superstructure-pile foundation model clarified that nonlinear soil-structure interaction greatly affected the structure response and suppressed the damage of superstructure and pile foundation.
\end{abstract}

Keywords: The Niigata-ken Chuetsu Earthquake, RC Building, Strong Motion, Field Survey, Response Analyses, Soil Structure Interaction 新潟県中越地震， RC 造建物，強震記録，現地調查，応答解析，相互作用

\section{1. はじめに}

2004 年新潟県中越地震では、十日町市、小千谷市の強震観測点 で、設計用地震動レベルを超える大振幅の加速度記録が多数観測さ れたが、周辺の RC 建物では大きな被害は見られなかった1)。この ように建物が大振幅の地震動を受けたにも関わらず、その被害が小 さいという状沉は以前から問題とされてきた。

1993 年釧路沖地震では、釧路地方気象台で $700 \mathrm{~cm} / \mathrm{s}^{2}$ を超える大 きな地震動が観測されたが、周辺の建物は軽微な被害に留まり、そ の要因について多くの研究が行われた2)。

1995 年兵庫県南部地震では、多地点での強震記録が得られたこ とから、建物群の耐震性能と入力地震動の面的な分布の関係につい て検討した事例が報告されている。例えば、文献3)では建物の被害 状況から建物 1 階の等価応答速度分布を評価し、文献4)では多地点 の観測記録や地盤構造から推定した地震動の空間分布と被害分布 から建物耐力を逆算している。これらの研究から、被害より逆算さ れた等価応答速度は実際の強震記録より小さく、被害と推定地震動
から推定された建物の耐力は実建物の平均的耐力より大きいこと がわかる。このような矛盾が生ずる原因としては、建物の耐力上昇、 地盤との相互作用、地震動の周期特性などが考えられるが、未だそ の原因は明確にされていない。

また、兵庫県南部地震については、個別の建物を対象とした地 震被害に関する検討事例も報告されている。例えば、文献5)では $\mathrm{RC}$ 造の中層共同住宅建物、文献6)では RC 造の学校建物の解析を 行い、実被害と解析結果の対応関係を検討している。文献7)では、 $\mathrm{SRC}$ 造の中高層建物を対象に、建物と地盤の相互作用による入力 低減効果が建物応答に与える影響を検討している。文献8),9)では、 上部構造と杭基礎のいずれかが被災した RC 系の中低層建物を対 象に検討を行い、上部構造の被害が軽微な場合には杭基礎に大きな 被害が生じ、上部構造に大きな被害が生じた場合には杭基礎の被害 は軽微であった事例を示している。ただし、これらの研究は、ある 程度の被害を受けた建物を対象とした検討であり、大きな被害を免 れた建物について詳細な検討が行われた事例は少ない。
本論文は，文献25）の内容に加筆してまとめたものである。

*1 東京電力(株) 工博

*2 東京電力株)

*3 (株)小堀鐸二研究所

*4 大阪大学大学院 教授
Tokyo Electric Power Company, Dr. Eng.

Tokyo Electric Power Company

Kobori Research Complex Inc.

Prof., Osaka University 
筆者らは、2004 年新潟県中越地震における十日町市での強震記 録を用いた仮想建物の地震応答解析を行い、基礎と地盤との非線形 相互作用や杭基礎の損傷が建物の応答低減に影響を与えることを 示した ${ }^{10)}$ 。しかし実建物を対象とした詳細な検討は行っていない。

以上の背景から、本研究では、新潟県中越地震において大振幅 の地震動を観測した JMA 小千谷地点 ${ }^{11)}$ の近くに建つ新潟県立小千 谷西高等学校を対象として、大きな被害を免れた要因を総合的に検 討することとした。検討においては、実強度を考慮して建物のモデ ル化を行うとともに、詳細な地盤調査を行って、表層地盤応答の評 価と地盤-杭基礎の非線形相互作用を考慮した検討を行った。本論 文では、まず建物概要と現地調査結果を報告する。次に、強震記録 を用いた地盤-杭-建物一体モデルによる地震応答解析結果を示す。 最後に、建物の実被害と解析結果の対応関係について分析寸る。

\section{2. 建物概要}

図 1 に、小千谷西高校と強震記録が観測された JMA 小千谷地点 および水仙の家 ${ }^{12)}$ の位置関係を示す。小千谷西高校と JMA 小千谷 地点との距離は約 $300 \mathrm{~m}$ 、水仙の家との距離は約 $1 \mathrm{~km}$ である。JMA 小千谷と水仙の家での観測記録の最大加速度は両地点とも $\mathrm{EW}$ 成 分が NS 成分より大きく、各々約 $900 \mathrm{~cm} / \mathrm{s}^{2}$ と約 $810 \mathrm{~cm} / \mathrm{s}^{2}$ であった。

小千谷西高校の校舎建物には、 $\mathrm{RC}$ 造の普通管理教室棟と特別教 室棟があり、両建物はほぼ同等の耐震性能である ${ }^{13)}$ 。但し、普通管 理教室棟では中越地震後に耐震補強工事が実施されているため、補 強前の建物の振動特性の把握が困難である。そこで、本研究では特 別教室棟を検討対象とした。

図 2 に特別教室棟の 1 階および基礎伏図、図 3 に B 通り軸組図 を示す。特別教室棟(延床面積 $3,429 \mathrm{~m}^{2}$ ) は昭和 41 年竣工の地上 3 階建(高さ $11.9 \mathrm{~m}) 、$ 地下階なしの $\mathrm{RC}$ 造であり、長辺方向 $(85.5 \mathrm{~m})$ はラーメン構造、短辺方向(11.8m)は耐震壁付ラーメン構造である。 長辺方向の外周部の構面は、腰壁・垂壁付梁と通常の柱の組み合 わせが主体であり、廊下側外周面の $\mathrm{B}$ 通りでは、約半数の柱が極 脆性柱となっている。

表 1 にコンクリート強度、表 2 に鉄筋強度を示す。また、構造 用階高と建物重量を表 3 に示す。地震前に実施された耐震 2 次診 断 ${ }^{13)}$ では、 $\mathrm{I}_{\mathrm{s}}$ 值 $\left(=\mathrm{E}_{0} \times \mathrm{S}_{\mathrm{D}} \times \mathrm{T}\right)$ は長辺方向の 1 階と 3 階で 0.4、短辺 方向の 1 階で 1.2 であった。基礎形式は、各柱位置のフーチング 下に複数本の $\mathrm{PHC}$ 杭(杭径 $30 \mathrm{~cm}$ 、杭長 $6 \mathrm{~m} 、 \mathrm{~A}$ 種)で支持した杭基 礎であり、杭本数は合計 368 本であった。

\section{3. 建物の被災度調査}

\section{1 建物の被災度判定結果}

図 2 に、1 階の損傷度調査結果を示す。損傷度 $\mathrm{I} \sim \mathrm{II}$ の柱が数 本確認されたが、図 4 に示すように腰壁と柱の境界位置に微小な 曲げひび割れが認められた程度である。この損傷度から、文献14) による被災度区分の判定を行った。表 4 に長辺 $(\mathrm{X})$ 方向の被災度判 定結果を示す。長辺方向の耐震性能残存率は約 99\%であり、被災 度区分は軽微であった。なお、短辺(Y)方向については無被害であ った。また水平器による床の傾斜計測を行った。図 2 に、1 階床 の傾斜計測結果を示す。各計測点の傾斜方向は同一でなく、建物

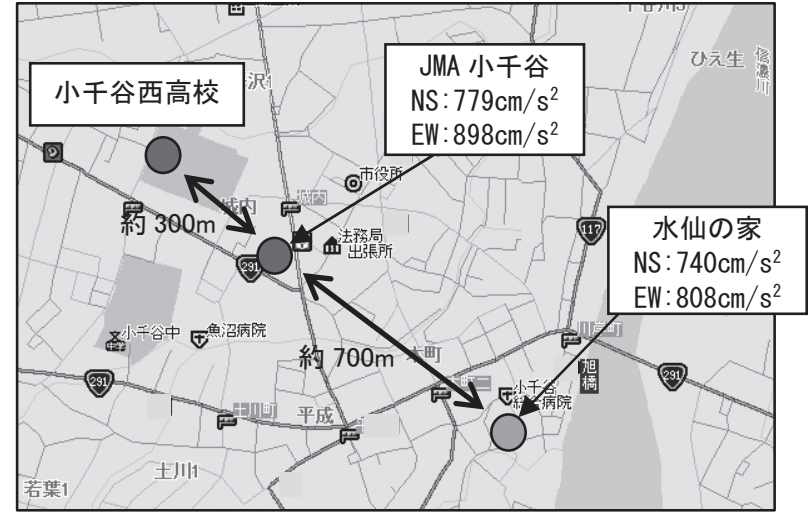

図 1 小千谷西高校と強震観測点の位置関係

表 1 コンクリート強度

\begin{tabular}{|c|c|c|}
\hline 設計基準強度 $\left(\mathrm{N} / \mathrm{mm}^{2}\right)$ & 圧縮強度試験 $\left(\mathrm{N} / \mathrm{mm}^{2}\right)$ & 使用範囲 \\
\hline 18.0 & 22.1 (平均) & 1 階から 3 階 \\
\hline
\end{tabular}

表 2 鉄筋強度

\begin{tabular}{|c|c|c|c|}
\hline 鉄筋種別 & 基準強度 $\left(\mathrm{N} / \mathrm{mm}^{2}\right)$ & 強度上昇率 & 鉄筋径(使用範囲) \\
\hline $\mathrm{SR} 235$ & 235 & 1.25 & 径 9(横補強筋,壁筋) \\
\hline $\mathrm{SR} 235$ & 235 & 1.25 & 径 19,22,25(主筋) \\
\hline
\end{tabular}

表 3 構造用階高と地震荷重用重量

\begin{tabular}{|c|c|c|c|}
\hline 階 & 構造用階高 $(\mathrm{m})$ & 重量 $w_{(}(\mathrm{kN})^{* 1}$ & $W_{i} \sum w_{(}(\mathrm{kN})$ \\
\hline 3 階 & 3.80 & 15718 & 15718 \\
\hline 2 階 & 3.80 & 14078 & 29796 \\
\hline 1 階 & 4.85 & 14911 & 44707 \\
\hline 基礎 & - & 12700 & 57407 \\
\hline
\end{tabular}

$* 1$ :積雪荷重は考慮しない。

が全体傾斜するほどの不同沈下は生じていないことから、杭基礎 に大きな被害が生じている可能性は低いと考えられる。但し、学 校関倸者によると建物周辺のコンクリート製の側溝については、 地震によりひび割れ被害が発生したとのことであった。

\section{2 部材損傷度に基づく本震時の最大層間変形角の推定}

まず文献15)の方法を用いて、1 階 B 通りの極脆性柱のひび割れ 幅に対応する本地震時の長辺方向の最大層間変形角を推定寸る。 文献 15)では、RC 部材の塑性変形はひび割れによって生ずるとい う考え方に基づいて、残留変形時の最大ひび割れ幅と部材角の関 係を評価している。また、残留変形と最大変形の関係は、最大変 形から武田モデルの除荷勾配に沿って除荷したときの変形を残留 変形とみな寸ことで評価している。以上を組み合わせると、残留 変形時の最大ひび割れ幅から最大変形角を推定することができる。

ここでは、1 階の B-13 柱および B-15 柱(内法高さ $1200 \mathrm{mm，シ}$ アスパン比 0.86)の損傷に基づいて最大変形角を推定する。これら の柱はせん断降伏先行部材であるが、被害調查では $0.2 \mathrm{~mm}$ の曲げ ひび割れが観察され、せん断ひび割れは観察されなかった。文献 15)の方法では、曲げ変形とせん断変形の割合を設定する必要があ るが、この段階では曲げひび割れ発生が先行し曲げ変形の占める 割合が多かったと推測される。そこで、曲げ変形割合 $\alpha$ は 1.0 と 仮定した。この仮定により、部材角は小さめに見積もられること になる。その他のパラメータについては、文献 15)の解説中の設定 值を用いた。以上のようにして評価した残留変形時最大ひび割れ 


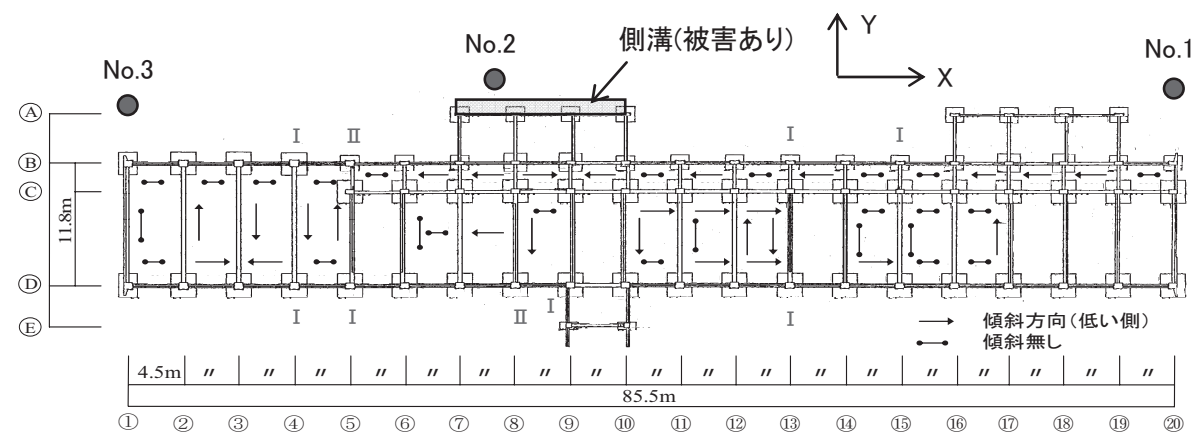

図 21 階および基礎伏図と被災度調查結果(ローマ数字は部材損傷度、○は地盤調查位置)

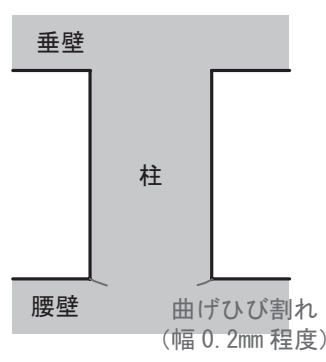

図 4 B 通り柱の

曲げひび割れ状況

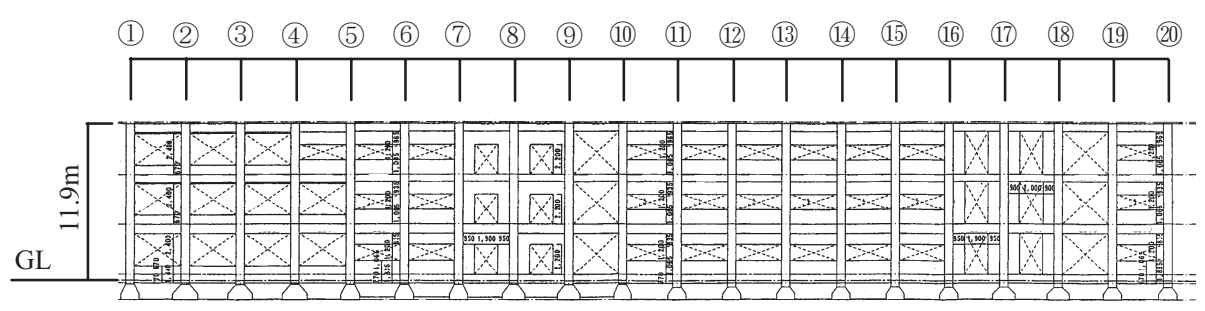

表 4 被災度区分判定結果(長辺)

\begin{tabular}{|c|c|c|}
\hline & $\begin{array}{c}\text { 耐震性能 } \\
\text { 残存率 }(\%)\end{array}$ & 判定 \\
\hline 3 階 & 99.1 & 軽微 \\
\hline 2 階 & 100.0 & 無被害 \\
\hline 1 階 & 98.7 & 軽微 \\
\hline
\end{tabular}

図 3 B 通り軸組図

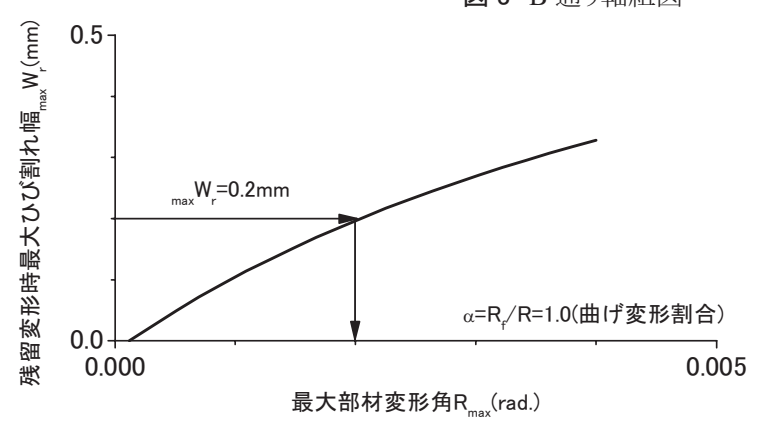

図 5 最大残留ひび割れ幅と最大部材変形角

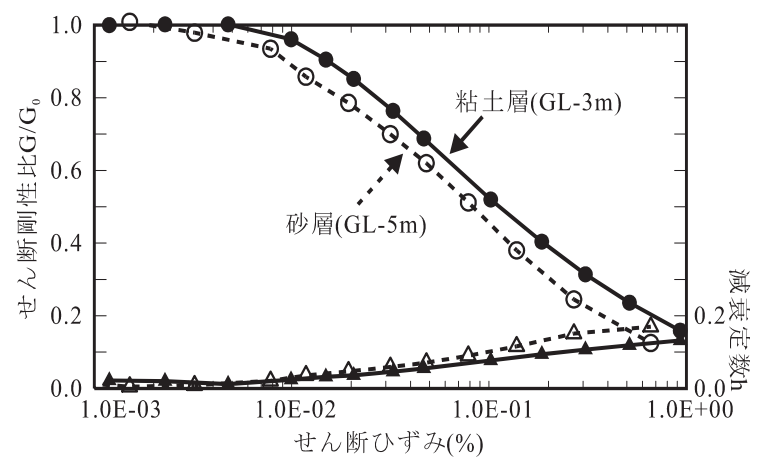

図 7 土の動的変形試験結果

幅一最大変形角関係を、図 5 に示す。この図から、0.2mm のひび 割れ幅に対応する部材の最大変形角は約 $1 / 500$ と推定される。

層の最大変形角を推定する際には、部材変形角との差を考慮す る必要があるが、後述するフレームモデルの荷重増分解析におい て層間変形角は部材角の $1 / 2$ 以下であったことから、本震時の 1 階の最大層間変形角は 1/1000 程度以下であったと推測した。

次に短辺方向について検討寸る。短辺方向については、地震に よるひび割れは観察されず無被害であった。そこで目安として、

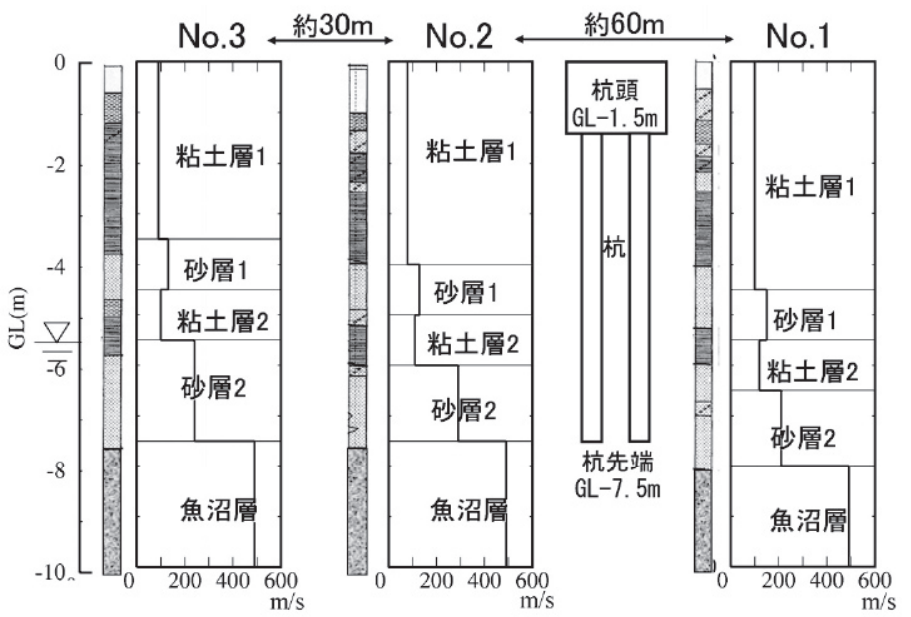

図 6 地盤調査結果(層序と $\mathrm{S}$ 波速度分布)と杭基礎の関係

表 5 地盤の解析定数

\begin{tabular}{|c|c|c|c|c|c|c|c|}
\hline \multirow{2}{*}{ 土質 } & \multirow{2}{*}{$\begin{array}{c}\text { 深度 } \\
(\mathrm{m})\end{array}$} & \multirow{2}{*}{$\begin{array}{r}\begin{array}{r}\text { 密度 } \\
\left(\mathrm{t} / \mathrm{m}^{3}\right)\end{array}\end{array}$} & \multicolumn{3}{|c|}{ S波速度 $(\mathrm{m} / \mathrm{s})$} & \multirow{2}{*}{$\begin{array}{c}\text { 基準歪み } \\
\gamma_{0.5}(\%)\end{array}$} & \multirow{2}{*}{$\begin{array}{c}\text { 最大減衰定数 } \\
h_{\text {max }} \% \text { \% }\end{array}$} \\
\hline & & & No.1 & No.2 & No.3 & & \\
\hline 粘土層1 & $3.5 \sim 4.5$ & 1.60 & 100 & 80 & 90 & 0.11 & 16 \\
\hline 砂層1 & $4.5 \sim 5.5$ & 1.70 & 150 & 130 & 130 & 0.08 & 18 \\
\hline 粘土層2 & $5.5 \sim 6.5$ & 1.60 & 120 & 110 & 100 & 0.11 & 16 \\
\hline 砂層2※ & $7.5 \sim 8.0$ & 1.70 & 210 & 290 & 240 & 0.08 & 18 \\
\hline 魚沼層 & - & 1.95 & 490 & 490 & 490 & 線形 & 線形 \\
\hline
\end{tabular}

14 通りの連層耐震壁脚部のせん断ひび割れ強度時 ${ }^{16}$ の 1 階の層間 変形角を算定してみると $1 / 3800$ であった。なお、せん断ひび割れ 強度時の曲げ変形については、外力が高さ方向に等分布すると仮 定して算出した。以上より、1 階の最大層間変形角が $1 / 3800$ 程度 以下であれば、実状に対応すると考えた。

4. 地盤の応答解析 


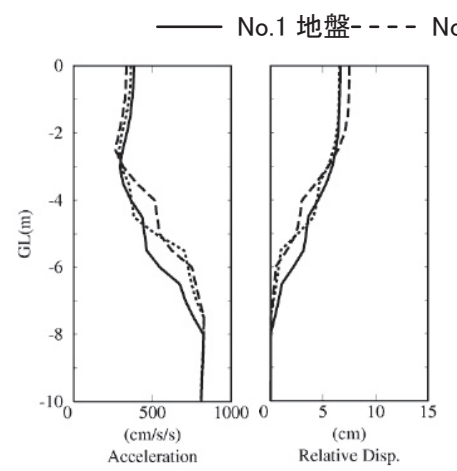

(X 方向 $)$

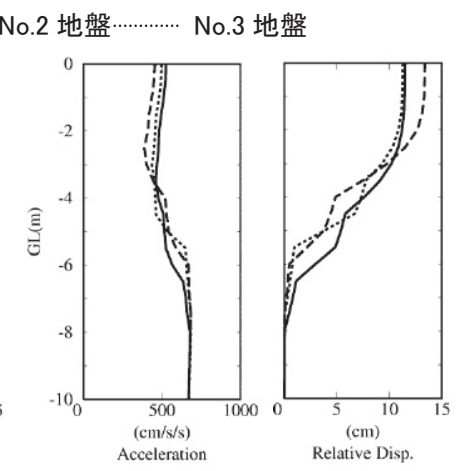

( $\mathrm{Y}$ 方向)

図 8 No.1〜3 地盤での地盤応答の深度分布

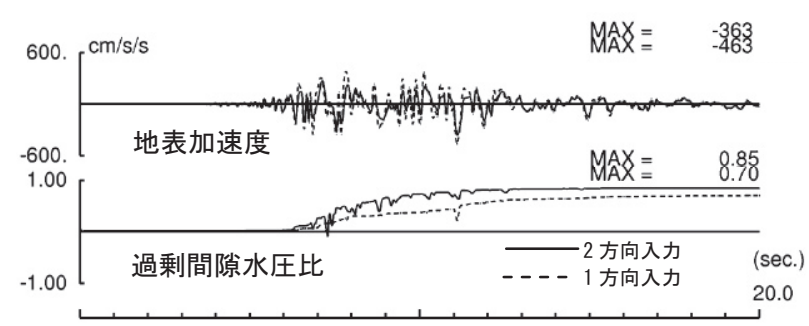

(a) X 方向,No.3 地盤

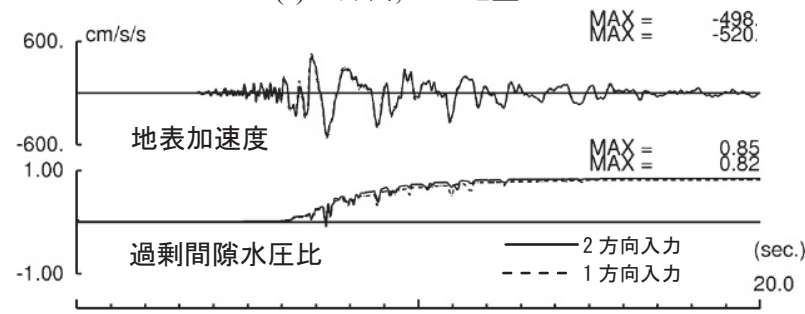

(b) Y 方向,No.3 地盤

図 9 地表加速度と砂層 2 での過剩間隙水圧比の時刻歴波形 (最大值は上段が 2 方向入力、下段が 1 方向入力)

\section{1 地盤の解析モデル}

地盤の解析モデルは、現地で実施したコーン貫入試験 $(\mathrm{CPT})$ と原 位置採取試料による動的変形試験結果をもとに設定した。図 2 に $\mathrm{CPT}$ 調查位置、図 6 に地盤構造の断面図、また図 7 に動的変形試 験結果を示寸。現地調查では、S 波検層も併せて行った。敷地地 盤はほぼ平行成層であり、4 層(上位から順に粘土層 1 , 砂層 1 , 粘 土層 2, 砂層 2)から構成される。また動的変形試験は、粘土層 (GL-3m) と砂層(GL-5m)での原位置採取試料に対して行った。なお、 本敷地地盤から約 $300 \mathrm{~m}$ の距離に位置する JMA 小千谷地点(図 1

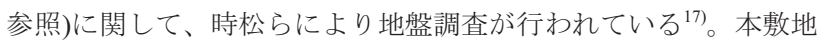
での魚沼層上面深度は、JMA 小千谷地点 $(\mathrm{GL}-13 \mathrm{~m})$ よりやや浅くな っている。

表 5 に本敷地の地盤定数を示す。地盤応答は、敷地が概称平行 成層であることから 3 次元土柱モデルを用いた水平 2 方向同時入 力解析 ${ }^{18)}$ により評価した。但し、図 6 に示すように建物の長辺方 向で $\mathrm{S}$ 波速度に若干違いがみられたため、No.1〜No.3 地盤につい て各々モデルを作成した。土の非線形モデルは H-D モデルとし、 動的変形試験結果をもとに設定した。また地下水位は GL-5.5m で あり、砂層 2 について液状化を考慮した。液状化パラメータ ${ }^{19}$ は、

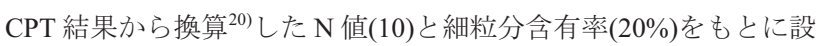



(X 方向,No.3 地盤, $\mathrm{h}=5 \%$ )

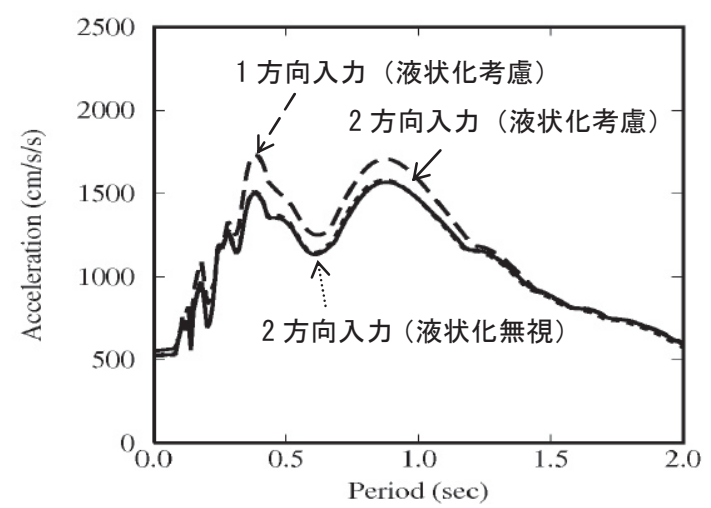

( $\mathrm{Y}$ 方向,No.3 地盤, $\mathrm{h}=5 \%$ )

図 10 水平 2 方向入力および液状化の影響

定した。

入力地震動は、魚沼層上面での露頭波に相当する水仙の家での 観測記録 ${ }^{12)}$ を用いた。なお、本敷地への入力地震動としての適用 性についてはJMA 小千谷(図 1 参照)での観測記録のシミュレーシ ヨン解析により別途確認している ${ }^{25)}$ 。また本研究では、観測記録 を建物各方向(長辺 X 方向 N020E、短辺 $\mathrm{Y}$ 方向 N110E)に变換して 用いることとする。

\section{2 地盤の応答解析結果}

図 8 に、No.1〜3 地盤の最大応答值分布を示す。いずれの地盤 も粘土層 2 の非線形化が進み、加速度は小さくなる。地盤変位は 粘土層 2 以浅で増幅し、Y 方向が X 方向に比べて大きい。なお、 No.1〜3 での地盤応答の差は小さい。

図 9 に、No.3 地盤の地表加速度と砂層 2 での過剩間隙水圧比(初 期有効上載圧に対する過剩間隙水圧の比)の時刻歴波形を $\mathrm{X}, \mathrm{Y}$ 各 1 方向入力した場合と比較して示す。過剩間隙水圧比は、最大 0.85 程度まで上昇するが完全には液状化に至らない。両方向とも 1 方 向入力に比べて 2 方向入力の結果は、過剩間隙水圧は上昇寸るが、 最大加速度は小さくなる。特に、Y 方向の入力による地盤の非線 形化の影響で、X 方向の応答の差が大きい。

図 10 に、No.3 地盤の地表での加速度応答スペクトル(減衰 5\%) を示す。 $\mathrm{X}$ 方向の応答は、 2 方向入力した場合の方が、周期約 1 秒以下で小さくなり、それより長周期では逆に大きくなる。Y 方 向では周期約 1.5 秒以下でやや小さくなるが、それより長周期で は大きな差は見られない。これは、図 8 に示すように、応答の小 さい X 方向が直交方向の入力の影響をより強く受けたことによる。 
また同図中には、砂層 2 の液状化を考慮しない場合の 2 方向入力 の結果も比較して示寸。これより本敷地では液状化の影響は小さ く、Y 方向の入力による地盤非線形性の影響を特に粘土層で強く 受けたことがわかる(図 8 参照)。なお、この水平 2 方向入力による 表層地盤の非線形化が、特に長辺方向の建物応答に大きな影響を 与えることは別途確認している ${ }^{25)}$ 。

本研究では、実被害との対応関係を分析することが目的である ため、建物と杭基礎の応答解析では 3 つの地盤モデルの各位置に 対応した応答結果を入力し、水平 2 方向同時入力した地盤応答を 用いることにより実状に即した検討を行うこととする。

\section{5. 建物之杭基礎の応答解析}

\section{1 建物の解析モデル}

図 11 に、建物-杭-地盤連成系の 3 次元モデルを示す。建物の梁. 柱はビーム要素でモデル化し、耐震壁はブレース置換でモデル化 した。梁・柱に取り付く腰壁・垂壁、袖壁については、その影響

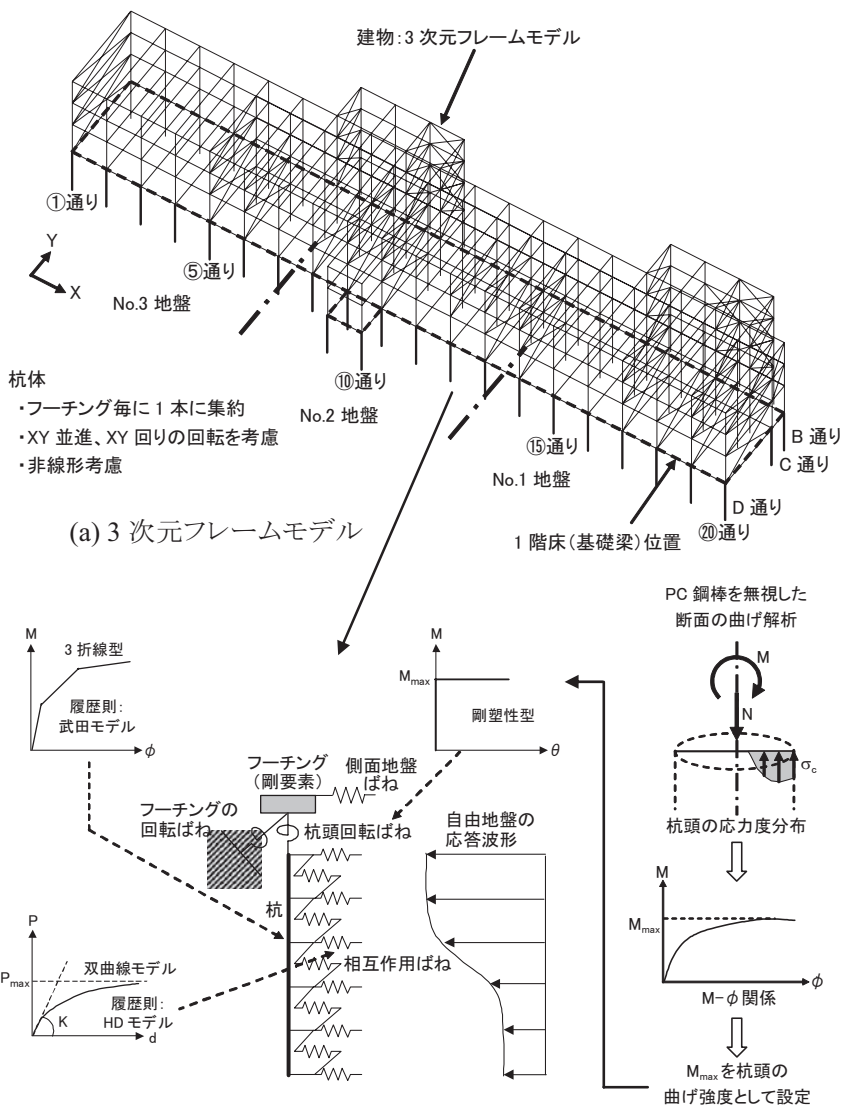

（b）杭基礎と相互作用ばねのモデル化

(c) 杭頭半接合条件の 設定方法

図 11 建物-杭一地盤連成系 3 次元モデル

表 6 解析厅ース

\begin{tabular}{|c|c|c|c|}
\hline Case & $\begin{array}{c}\text { 杭体と } \\
\text { 相互作用ばね }\end{array}$ & $\begin{array}{c}\text { 側面 } \\
\text { 地盤ばね }\end{array}$ & $\begin{array}{c}\text { 杭頭 } \\
\text { 接合条件 }\end{array}$ \\
\hline 1 & 線形 & - & 剛接合 \\
\hline 2 & 非線形 & - & 剛接合 \\
\hline 3 & 非線形 & 考慮 & 剛接合 \\
\hline 4 & 非線形 & 考慮 & 半接合 \\
\hline
\end{tabular}

を考慮して強度、剛性を算定した。部材の強度は、文献21)の算定 式を用いて算定した。本検討は実挙動の把握を目的とすることか ら、せん断強度は mean 式を用いて算定した。また、コンクリート 強度は表 1 に示すコア抜き圧縮強度試験の平均值を用い、鉄筋強 度には表 2 に示寸平均強度上昇率 22 を考慮した。

曲げ降伏先行部材（以下、曲げ部材）の割線剛性低下率は菅野 式を用いて算定し、せん断降伏先行部材（以下、せん断部材）で は降伏変形角を $1 / 250$ として剛性低下率を算定した。上述の剛性 低下率は、変形成分別の剛性低下率ではなく、曲げ・せん断・付

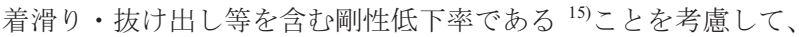
曲げ部材、せん断部材ともに、曲げ変形に剛性低下を考慮した復 元力特性を設定し、せん断変形は弾性とした。その際に、せん断 部材は、逆対称曲げを想定して等価な曲げ剛性低下率を設定した。 柱・梁接合部は可撓域を考慮して危険断面から部材せいの $1 / 4$ 入 った位置までを剛域とした。一方、菅野式は内法長さに対する剛 性低下率であることから、接合部可撓域を考慮したことによる弾 性剛性の低下の影響を補正して剛性低下率を設定した。なお、曲 げ部材とせん断部材の履歴特性は、それぞれ武田モデルと原点指 向モデルとし、建物の減衰は $3 \%$ の瞬間剛性比例型とした。

\section{2 杭基礎の解析モデル}

杭は、各フーチングで 1 本の曲げせん断棒に集約した群杭モデ ル(計 63 本)とした。杭の曲げ変形には、長期軸力時の M- $\phi$ 関係に 基づいて 3 折線型の復元力特性を設定し、履歴則は武田モデルと した。解析では、水平 2 方向同時入力による計算で求めた各杭位 置の地盤応答を、杭の各質点に取り付けた相互作用ばねを介して 入力した。相互作用ばねの初期定数は、地盤の応答解析で求めた 等価地盤定数を用いて三次元薄層法によるリング加振解から評価 した ${ }^{23)}$ 。また地震応答解析では、杭と地盤との相対変位により生 じる非線形性を考慮した。基礎埋め込み部(深さ $1 \mathrm{~m})$ の側面地盤ば ねは、三次元薄層法により求めた基礎全体の地盤ばねから基礎底 面部の地盤ばねを差し引くことにより評価した ${ }^{24)}$ 。

杭頭接合部は、杭のフーチングへの貫入量が $10 \mathrm{~cm}$ 程度である こと、また PC 鋼棒によるフーチングへの定着が十分でなく、地震 時に緩みが生じた可能性が考えられることなどから半接合条件を 以下のように考慮した。まず図 11(c)に示すように、杭の PC 鋼棒 を無視し、長期軸力のみを考慮した断面の曲げ解析により M- $\phi$ 関 係を求め、その最大曲げモーメントを $\mathrm{M}_{\max }$ とした。次に、杭頭に 剛塑性型の回転ばね(M- $\theta$ 関係)を取り付け、その強度を $\mathrm{M}_{\max }$ とす ることにより半接合条件をモデル化した。

\section{3 解析ケース}

表 6 に、解析ケースを示す。解析では、杭体と相互作用ばねの 非線形性の影響や、基礎埋め込み部の側面地盤ばね、および杭頭 の接合条件による影響を検討した。初期モデル(Case-1)は、杭体と 相互作用ばねを線形とし、側面地盤ばねは無視して、杭頭は剛接 合とした。これに対して、Case-2 は杭体と相互作用ばねの非線形 性を考慮した場合、Case-3 はさらに側面地盤ばね考考慮した場合、 また最終モデル(Case-4)は杭頭半接合条件を考慮した場合である。 ほか比較のため、建物中央(No.2 地盤)での地表面応答を入力とし た基礎固定モデル(Case-0)による応答解析も行った。 
表 7 建物の固有周期(s)

\begin{tabular}{|c|c|c|c|c|c|}
\hline \multirow{2}{*}{} & \multicolumn{2}{|c|}{ 微動計測結果 } & \multicolumn{3}{|c|}{ 固有值解析結果 } \\
\cline { 2 - 6 } & $\begin{array}{c}\text { 基礎 } \\
\text { 固定 }\end{array}$ & $\begin{array}{c}\text { 地盤 } \\
\text { 連成系 }\end{array}$ & $\begin{array}{c}\text { Case-0 } \\
\text { (基礎固定) }\end{array}$ & $\begin{array}{c}\text { Case-1 } \\
\text { (初期物性) }\end{array}$ & $\begin{array}{c}\text { Case-1 } \\
\text { (等価物性) }\end{array}$ \\
\hline 1 次 & 0.23 & 0.33 & 0.18 & 0.28 & 0.64 \\
\hline 2 次 & 0.20 & 0.29 & 0.12 & 0.24 & 0.60 \\
\hline
\end{tabular}

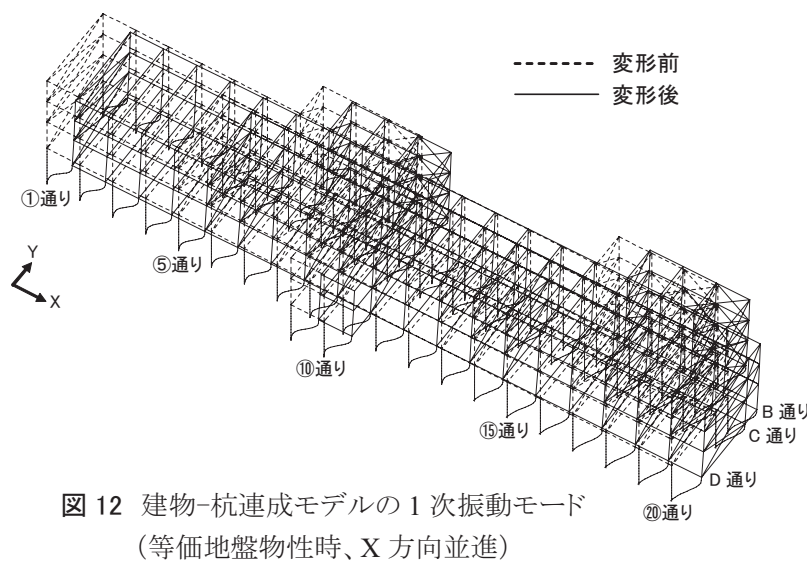

\section{4 建物の固有周期と静的荷重増分解析結果}

建物の固有周期を把握するため、常時微動計測を行った。常時 微動は、地表面と建物 1 階及び 3 階で同時に計測し、地表面及び 1 階に対する 3 階の伝達関数から卓越周期を評価した。

表 7 に、計測結果を示す。微動計測による基礎固定時の固有周 期は長辺が $0.23 \mathrm{~s}$ 、短辺が $0.20 \mathrm{~s}$ であるのに対して、地盤-建物連成 系の固有周期は、両方向とも約 1.5 倍(長辺: $0.33 \mathrm{~s}$, 短辺: $0.29 \mathrm{~s}$ ) に長 周期化する。この結果から、本建物の振動特性は地盤との相互作 用の影響を強く受けることがわかる。また Case-0 と Case-1' (Case-1 の相互作用ばねを微動計測時に合わせて初期地盤物性で評価した 場合)の固有值解析を行った。解析結果は、Case-0 の Y 方向を除い て、微動計測の卓越周期の $0.80 \sim 0.84$ 倍の範囲にあり、やや硬め であるが概ね対応している。

図 12 に、1 次固有モード(Case-1)を示す。地盤と基礎の変形が 卓越し、建物の挙動は剛体的であることが分かる。そこで、静的 荷重増分解析では、通常の $\mathrm{Ai}$ 分布に加えて、剛体モードを仮定し た荷重分布（以下、等分布）による検討を行った。

図 13 に、静的荷重増分解析の結果を示寸。 $\mathrm{Ai}$ 分布では X 方向 の 2 階の変形が先行しているが、等分布では 1 階の変形が先行し ている。現地調査では 1 階の柱の一部に曲げひび割れが認められ たが、2 階は無被害であった。このことから、本震時の外力分布 は等分布に近かったと考えられる。

\section{5 建物の応答解析結果}

図 14 に、 X,Y 両方向の建物の最大層間変形角を示す。X 方向の 基礎固定モデル(Case-0)は、 2 階の層間変形角( $1 / 240)$ が最大となり、 2 階で無被害であった実状と対応していない。また Case-1 は 1 階 で最大層間変形角 $(1 / 380)$ が生じ、地盤との相互作用と基礎梁の影 響により Case-0 に比べて応答は小さくなるものの、依然として損 傷度から推定した最大層間変形角(1/1000)を超えて実状とは対応



(a) X方向

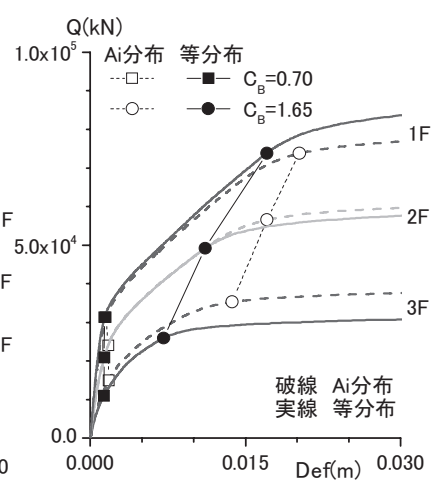

(b) Y 方向
図 13 静的荷重増分解析結果(層せん断力一層間変位)

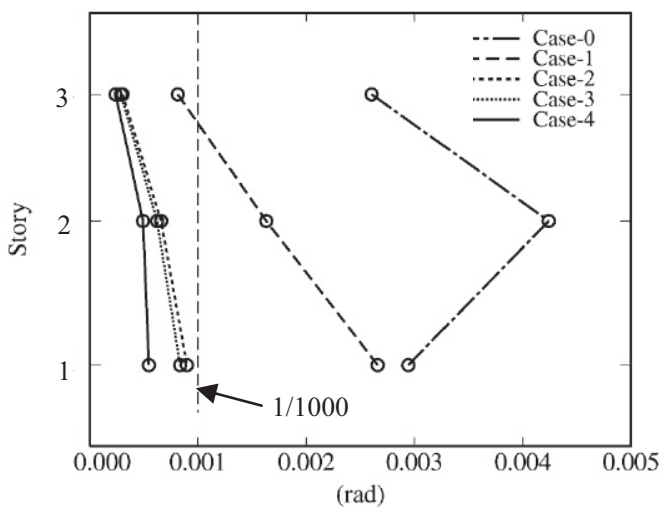

(a) $\mathrm{X}$ 方向

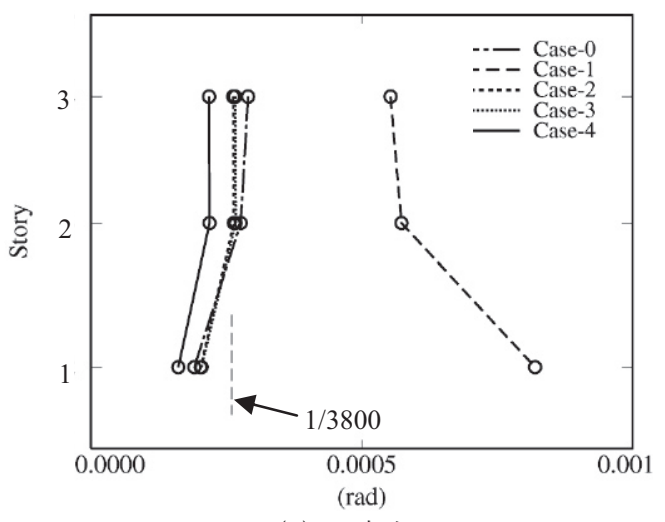

(b) Y 方向

図 14 建物の最大層間変形角

(X力方はフレーム B、Y 方向はフレーム 10 を示す)

しない。一方、相互作用ばねと杭体の非線形性を考慮した Case-2 では、最大層間変形角(1/1110)が 1 階で生じており、1/1000 以下に 収まる。また Case-3(1/1200)は、Case-2 に比べて応答が若干低減す るものの両者に大きな差が見られず、側面地盤ばねの影響は小さ い。最終的に杭頭半接合条件を考慮した Case-4 では、1 階で最大 層間変形角が $1 / 1830$ となり建物被害の害状と対応寸る。

Y 方向については、連層耐震壁脚部のせん断ひび割れ強度時 ${ }^{16)}$ の 1 階の層間変形角(1/3800)を図中に併記した。図より、非線形相 互作用を考慮した Case-2〜4 の 1 階の最大層間変形角は、せん断 
ひび割れ強度時の変形角を下回り、ひび割れが観察されなかった ことと対応している。

以上の結果から、建物の応答結果については Case-2,3,4 の解析 結果が被害の実状と対応することを確認した。次節では、この建 物応答の低減について相互作用の観点から分析寸る。

\section{6 相互作用ばねと基礎入力動}

図 15 に、杭頭位置で集約した水平地盤ばねの履歴曲線を示す。 $\mathrm{X}, \mathrm{Y}$ 両方向とも建物と地盤の相対変位は Case-4 が Case-1 に比べて 大きくなり、相互作用ばねの非線形化が進む。また、図中には最 大相対変位が発生した時刻でのばね值を示しているが、Case-1 に 対する Case-4 のばね值の比率は X 方向で 0.28 倍、 $\mathrm{Y}$ 方向 0.14 倍 に低下している。また、この建物と地盤の相対変位は、前述の建 物周辺の側溝にみられたひび割れ被害が発生した要因の一つと考
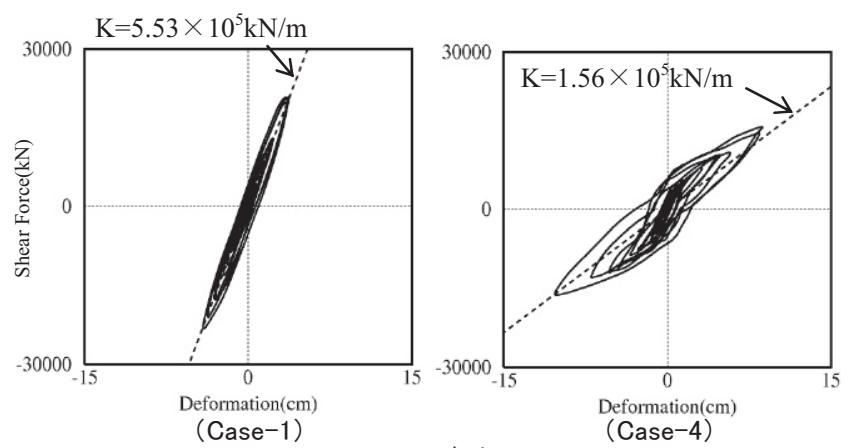

(a) $\mathrm{X}$ 方向
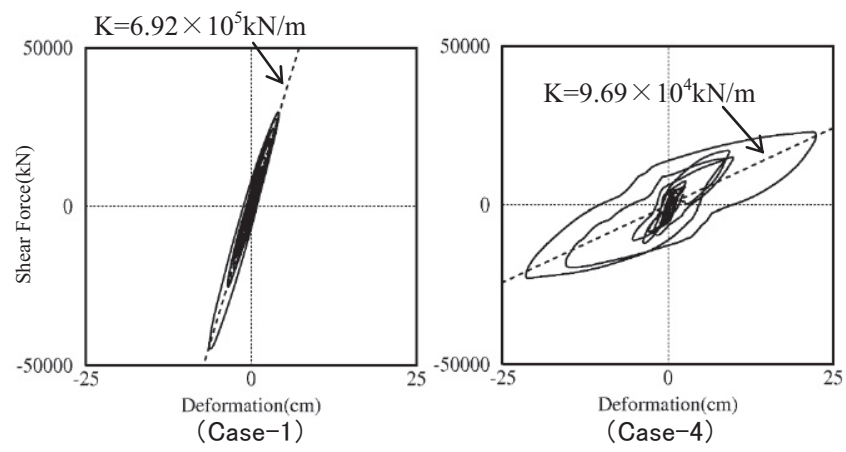

(b) Y 方向

図 15 杭頭位置で集約した水平地盤ばねの履歴曲線 ( $\mathrm{X}, \mathrm{Y}$ 方向 $)$



図 16 地表面応答(No.3 地盤)とCase-4 の建物 1 階の床応答、 および基礎入力動の加速度応答スペクトル $(\mathrm{X}$ 方向,減衰 5\%)
えられるが、定量的な対応関係については依然検討の余地がある。

図 16 に、X 方向の地表面応答(No.3 地盤)と Case-4 の建物 1 階 の床応答、および建物への入力地震動に相当する基礎入力動の加 速度応答スペクトル(減衰 5\%)を比較して示す。なお、基礎入力動 は、建物を取り去った無質量基礎を持つ杭基礎の地震応答解析に より求めた ${ }^{23)}$ 。地表面応答は、地盤の 1 次卓越周期(約 0.8 秒)およ び周期 0.2 0.4 秒に大きな振幅成分がみられる。建物 1 階の床応 答は周期約 1.1 秒付近に 1 次ピークがみられ、表 7 に示した地盤建物連成系の 1 次固有周期 0.64 秒(等価地盤物性時)に比べて長周 期化する。これは、図 15 に示した相互作用ばねの非線形化に対応 する。また基礎固定時の 1 次固有周期 0.18 秒付近に着目すると、 基礎入力動は自由地盤応答より小さく、1 階床応答は基䃈入力動 よりさらに小さくなる。

\section{7 杭基礎の応答解析結果}

図 17 に、上部構造からの慣性力と杭頭位置での地盤変位および Case-2 と Case-4 の杭の応答曲率波形( $\mathrm{Y}$ 方向、時刻 5 秒〜 15 秒)を 示す。Case-2 では、上部構造からの慣性力が最大となる時刻 7.5 秒に、杭頭と層境界の両方で曲率が最大となる。また同時刻に、 杭先端位置に対する杭頭位置での地盤変位も最大となり、これに より杭応答は増大して、杭頭と層境界の両方で終局曲率 $\phi_{\mathrm{u}}$ を上回 る結果となる。この結果から、杭頭が剛接合されている場合は、

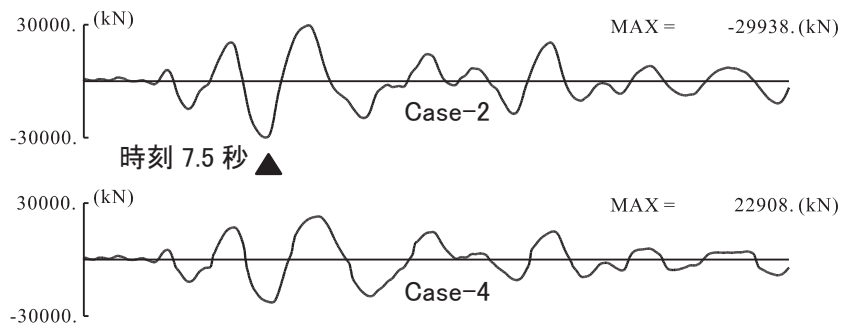

(a) 上部構造からの慣性力

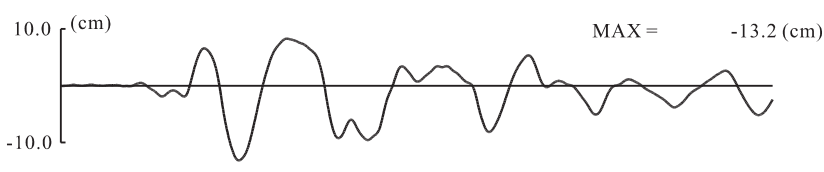

(b) 杭頭位置での地盤変位 (Case-2, Case-4 で共通)



(c) 杭の曲率

10. (sec.)

図 17 杭の応答曲率波形 (Case-2, Case-4, Y 方向) 点線は地盤震動による曲率成分、最大值は下段が地盤震動分 


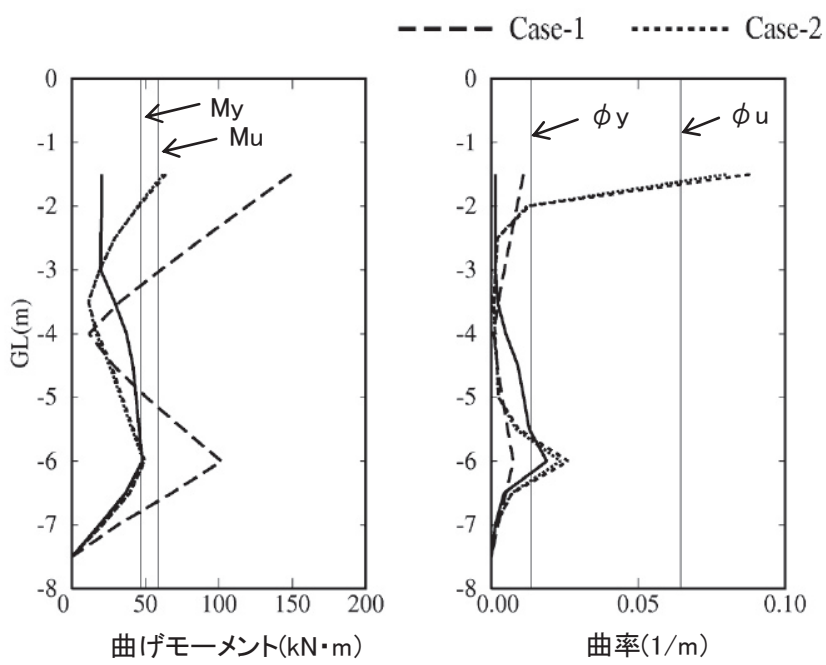

(a) $\mathrm{X}$ 方向

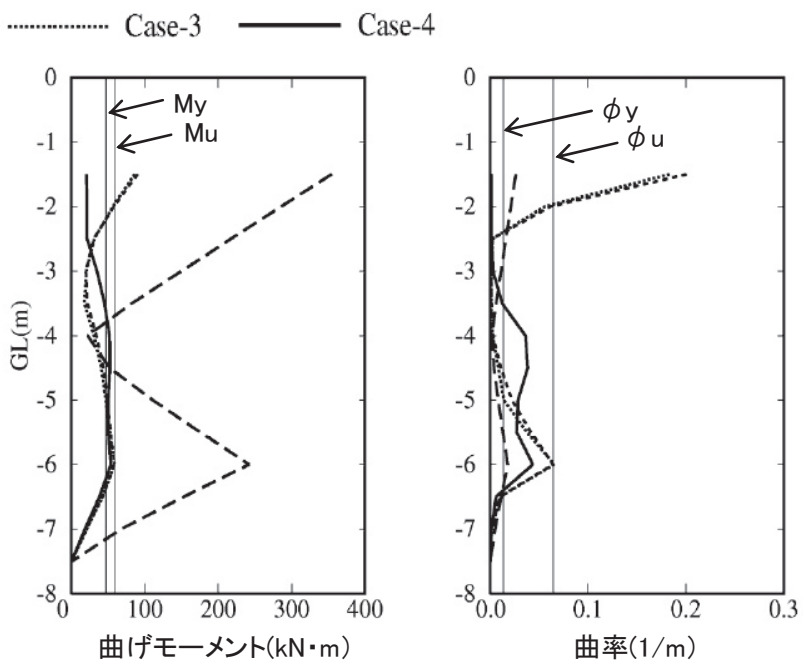

(b) Y 方向

図 18 杭の最大曲げモーメントと最大曲率 (フレーム 10、中央杭)

杭基礎に大きな被害が生じたものと考えられる。また、Case-4の 層境界での曲率は、地盤震動による曲率については Case-2 と同程 度であるが、上部構造からの慣性力が Case-2 よりも小さいため、 $\phi_{\mathrm{u}}$ を下回る曲率となる。

図 18 に、杭の曲げモーメントと曲率の最大值分布を示す。 Case-1 の X 方向は杭頭で終局モーメント $\mathrm{M}_{\mathrm{u}}$ を上回り、Y 方向は 杭頭と層境界で $\mathrm{M}_{\mathrm{u}}$ を大きく超える。Case-2,3でも杭頭を剛接合と しているため塑性化が進み、杭頭では終局曲率 $\phi_{\mathrm{u}}$ を大きく上回る。 一方、杭頭半接合を考慮した Case-4 の杭応力は杭頭と層境界とも に $\mathrm{M}_{\mathrm{u}}$ を下回り、曲率はいずれも $\phi$ u以に収まる。

以上の解析結果と、建物および杭基礎に大きな被害が生じなか った実状を考慮すると、中越地震における本建物の杭頭部は半接 合条件に近かったものと考えられる。

\section{6. まとめ}

本研究では、強震観測点近傍に建つ小千谷西高校を対象に、現 地調查と建物-杭-地盤連成系 3 次元モデルによる地震応答解析を実 施し、実被害と解析結果の対応を検討した。

(1) 建物の現地調査より、中越地震における建物の被災度区分は、長 辺方向が軽微、短辺方向が無被害であることを確認した。杭基礎 は、床の傾斜計測から、大きな被害が生じている可能性は低いと 推定される。また、部材の損傷度から、本震時の長辺方向最大層 間変形角は $1 / 1000$ 以下であったと推定した。

(2) 地盤調査結果に基づき地盤モデルを作成し、水仙の家での観測記 録を用いた有効応力解析を実施した。その結果、敷地全体はほぼ 同じ応答を示して完全に液状化していないこと、また GL-6m 以 浅の軟弱な粘土層が強非線形化したことがわかった。

(3) 長辺方向の建物応答は、建物の実強度を考慮した基礎固定モデル では 2 階で最大層間変形角(1/240)が生じ、2 階が無被害という実 際の状況と対応しなかった。また、地盤との相互作用を考慮した 線形ばねを取り付けた解析でも 1 階で最大層間変形角 $1 / 380$ が生 じ、実状と対応しなかった。一方、地盤との非線形相互作用と杭 頭の半接合条件などを考慮することにより、最大層間変形角は 1
階で $1 / 1830$ となり、損傷度から推定した最大層間変形角(1/1000) を下回る結果が得られた。これは、基礎の応答が地表面応答に比 べて周期約 0.2 秒以上で低減したこと、さらに相互作用ばねが非 線形化したことによると考えられる。

(4) 短辺方向の建物応答は、非線形相互作用を考慮した Case-2〜4で、 せん断ひび割れ強度時の 1 階層間変形角 $1 / 3800$ 下回り、ひび割れ が観察されなかったことと対応した。

(5) 杭の最大曲率は、杭頭の半接合条件を考慮することにより、杭頭 および地中部の層境界で終局点以内に収まり、損傷が小さいと推 測された実状と対応する結果となった。

以上、建物と杭基礎の被害低減には、杭と地盤の非線形相互作用 効果と地震時の杭頭固定度の低下が大きく寄与することを確認した。 また、建物の耐力上昇、表層地盤の非線形化などを総合的に考慮し た 3 次元フレームモデルで応答解析を行うことにより、新潟県中越 地震での実建物の挙動が説明可能であることを示した。

\section{謝辞}

本研究を進めるに当り、新潟大学・加藤大介教授に御指導を賜り ました。また、新潟県教育委員会ならびに小千谷西高等学校の高山 俊彦前校長、若杉伸事務長から多大な御協力を頂きました。本研究 で用いた水仙の家での強震記録は、小千谷総合病院、三菱地所設計、 大成建設より提供頂いたものです。ここに記して、謝意を表します。

\section{参考文献}

1) (社)日本建築学会：2004 年 10 月 23 日新潟県中越地震災害調査報告書、 2006.8

2) (社)日本建築学会地震災害委員会：1993 年釧路沖地震に関する総合シン ポジウム、1994.12

3) 市之瀬敏勝、石川小百合、前田匡樹、壁谷澤寿海 : 学校建築の被災状況 から見た兵庫県南部地震の応答速度、日本建築学会東海支部研究報告集、 第 34 号、pp.205-208、1996.2

4) 宮腰淳一、林康裕、田村和夫 : 被害データと地震応答解析に基づく建物 群の耐震性能に関する考察、第 10 回日本地震工学シンポジウム、 pp.327-332、1998

5) 松森泰造、小谷俊介 : 鉄筋コンクリート造建物の地震被害と弾塑性応答 
解析 -1995 年兵庫県南部地震における”ジュネス六甲”の検討一、日本建築 学会構造系論文集、第 505 号、pp.101-106、1998.3

6) 田才晃、北田朋子 : 柱が曲げ破壊した 1995 年兵庫県南部地震による被荻 $\mathrm{RC}$ 造建物の被害分析、第 10 回日本地震工学シンポジウム、pp.345-348、 1998

7) 安井譲、井口道雄ほか：1995 年兵庫県南部地震における基礎有効入力動 に関寸る考察、日本建築学会構造系論文集、第 512 号、pp.111-118、1998.10

8) 佐原守、亀井功ほか：兵庫県南部地震で被災した上部構造-杭系の被害分 析 一杭基礎が損傷した事例-(その 1)〜(その 3) 日本建築学会大会学術講 演梗概集(九州)、B-1、pp.509-514、1998.9

9) 元井康雄、佐原守ほか: 兵庫県南部地震で被㷋した建物-杭系の被害分析 杭基礎がほぼ無損傷の事例-(その 1)〜(その 3)、日本建築学会大会学術講 演梗概集(九州)、B-1、pp.515-520、1998.9

10)宮本裕司、土方勝一郎ほか : 2004 年新潟県中越地震での地震動と建物応 答に関寸る研究(その 1)〜 (その 3)、日本建築学会大会学術講演梗概集(関 東)、B-2、pp.455-460、2006.9

11)気象庁: 気象庁震度観測点一覧表、 http://www.seisvol.kishou.go.jp/eq/kyoshin/jma_sindo.htm

12)溜正俊、铇田隆 : 免震建物の地震観測記録と振動解析結果、新潟県中越 地震被害調查報告会梗概集、pp.111-116、2004

13)新潟県建築設計協同組合：「平成 15 年耐震診断報告書

14)国土交通省住宅局建築指導課：「震災建築物の被㷋度区分判定基淮および 復旧技術指針」、(財)日本建築防災協会、2001.9

15)(社)日本建築学会：「鉄筋コンクリート造建物の而震性能評価指針（案）・ 同解説」、2004
16)(社)日本建築学会：「鉄筋コンクリート造建物の勒性保証型耐震設計指針 (案) ・ 同解説」、1997

17)時松孝次、関口徹 : K-NET・JMA 小千谷の強震記録に見られる土の非線 形性状と室内試験から求めた動的変形特性との関係、日本建築学会構造 系論文集、第 603 号、pp.63-68、2006.5

18)藤村和也、沖見芳秀: 液状化解析に用いる 3 次元マルチスプリングモデ ルの基礎的検討、土木学会第 55 回年次学術講演会、2000

19)Iai, S. and Matsunaga, Y. et al. : Strain Space Plasticity Model for Cyclic Mobility, Soils and Foundations, Vol.32, No.2, pp.1-15, 1992.6

20)(社)日本建築学会 :「建築基礎構造設計指針」、2001

21)(財)日本建築センター：「建築物の構造規定 1997 年版」

22)(社)日本建築学会：「建築物の限界状態設計指針」、2002

23)宮本裕司、酒向裕司、古山田耕司、三浦賢治：1995 年兵庫県南部地震の 観測記録を用いた液状化地盤における杭基礎構造物の応答に関する解析 的検討、日本建築学会構造系論文集、第 493 号、pp.23-30、1997.3

24)喜多村英司、宮本裕司、三浦賢治、増田潔 : 埋込夕を有寸る群杭基礎の 地震応答性状に関寸る研究、日本建築学会構造系論文集、第 492 号、 pp.53-60、1997.2

25)土方勝一郎、杉山達也ほか: 新潟県中越地震における $\mathrm{RC}$ 造学校建物を対

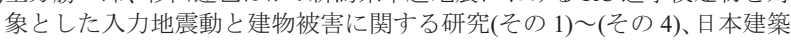
学会大会学術講演梗概集(福岡)、B-2、pp.151-158、2007.9

(2008年 2 月 7 日原稿受理， 2008 年 5 月 27 日採用決定) 